\title{
THE EFFECT OF LEARNING GOAL ORIENTATION ON SELF-PERCEIVED EMPLOYABILITY WITH CAREER ADAPTABILITY AS A MEDIATOR
}

\author{
Faadhilah Arnie Miftah \\ Department of Industrial and Organizational Psychology, Faculty of Psychology, \\ University of Airlangga, Surabaya, Indonesia \\ E-mail: arnie.miftah@gmail.com
}

\begin{abstract}
Learning goal orientation is an individual characteristic that relatively stable and characterized by efforts to develop competence and perseverance in the face of obstacles (Dweck, 1986). A study shows that learning goal orientation is related to career adaptability (Tolentino et al., 2014), but few studies shows the relationship between learning goal orientation and career outcomes such as self-perceived employability. This study investigates the role of career adaptability on mediating the effect of learning goal orientation and self-perceived employability. Participants of this study were 69 college students from various disciplines and several universities in Indonesia. Data were collected using Learning Goal Orientation scale (Button et al., 1996), The Career Adapt-Abilities Scales Form 2.0 (Savickas \& Profeli, 2012), and Student Self-Perceived Employability (Rothwell et al., 2009). Overall, the findings of this study show that career adaptability plays a mediating role in the effect of learning goal orientation on self-perceived employability.
\end{abstract}

\section{KEY WORDS}

Learning goal orientation, career, adaptability, self-perceived employability.

Industrial revolution era 4.0 not only creating new opportunities but also challenges for individuals to increase competitiveness to be able to adapt to the needs in this era. Changes in this era will provide many new job opportunities that will replace some types of work that are not in line with the development. Over the next 15 years, all countries will face largescale labor transitions because automation replaces some jobs and labor demand will also shift (Manyika et al., 2017). In dealing with this change, the workforce is required to have adequate skills so that they can compete and adapt to the demands of the world of work.

College students are individuals who will enter the workforce. Global trends show that young people are the most vulnerable to employment crises (ILO, 2013; Tolentino et al., 2014). New graduates often find it difficult to enter the labor market and get suitable jobs because of the lack of work experience or professional relations (Koen et al., 2012). Challenges and competition in the world of work today require college students to have the ability to obtain the desired work (employability). Rothwell and Arnold (2007) define employability as the individual's ability to get and keep his job. Employability is one result of a person's ability to adapt to environmental demands (adaptation result).

To be able to adapt well, individuals need willingness and readiness in the face of change. In career construction theory, the individual's readiness to change and the willingness to deal with career uncertainty with appropriate responses is called adaptivity (Savickas \& Profeli, 2012). Adaptivity can be measured in various indicators, such as learning goal orientation, proactivity, career optimism, and big five personality characteristic (Rudolph et al., 2017). In this study, adaptivity was measured using individual self-regulation indicators, that is learning goal orientation. Individuals who have high learning goal orientation have adaptive response patterns such as persistence, increasing effort in achieving goals, and enjoying challenges (Yi \& Hwang, 2003). Veiga and Turban (2014) explain that individuals who focus on learning goal orientation have better self-regulation during the process of finding work and are more successful in finding work.

Many studies have examined the relationship between adaptivity and career outcomes, but there are still few studies that examine the role of mediators in these relationships. 
Savickas and Profeli (2012) assume that the relationship between adaptivity and adapting responses can be mediated by career adaptability. Rossie (2015; Udayar et al., 2018) explains the role of career adaptability in mediating the relationship between individual dispositions in career behaviors, where career adaptability can generate strong adaptive functions that allow dispositions to fit with environmental characteristics. Based on this explanation, this study aims to examine the role of career adaptability in mediating the relationship between learning goal orientation and self-perceived employability in college students.

\section{LITERATURE REVIEW}

Learning goal orientation is an individual characteristic that relatively stable and characterized by efforts to develop competence and perseverance in the face of obstacles (Dweck, 1986). Button et al. (1996) explain that there are some indicators of individuals who have learning goal orientation that is involved in challenging activities, have a desire to develop themselves and tendency to use the past performance as a standard evaluation of current performance. Individuals with learning goal orientation view intelligence as a flexible trait that can be developed continuously through experiences and effort. Learning goal orientation individuals attempt to develop their ability, overcome obstacles, and improve competency (Creed et al., 2009).

Career adaptability is a psychosocial construct that indicates individual resources in overcoming and anticipating tasks, transitions, and traumas in the occupational role that change individual's social life on a small or large scale (Savickas \& Profeli, 2012). Career adaptability resources including attention about the future (concern), discipline and responsibility in making decisions regarding the future (control), curiosity to find information about opportunities (curiosity), and individual confidence in solving problems and doing everything needed to overcome obstacles (confidence).

Employability in general, defined as individual capability to obtain and maintain a desirable job (Rothwell \& Arnold, 2007). Employability can be conceptualized as antecedent or outcomes. Antecedent approach view employability as an ability, skill, attitude, and behavior that help individuals to a new job or maintaining their current job (Fugate et al., 2004; Van Dam, 2004). On the other hand, the outcome approach review employability subjectively by asking individuals to assess their chances of obtaining and maintaining employment or what is referred to as self-perceived employability (De Cuyper et al., 2011; Rothwell \& Arnold, 2007).

Rudolph et al. (2017) explain that each individual has different willingness (adaptivity) and ability (career adaptability) in developing beliefs and showing behaviors (adapting responses) in the face of changing environmental conditions, which will also affect the suitability or positive integration of their work role (adaptation result). Individuals who have willingness to involve in adaptation behavior can bring out the resources needed to deal with changing situations (Savickas \& Profeli, 2012). Individual's adaptivity affects career adaptability, which also influences adaptation responses and adaptation outcomes (Rudolph et al., 2017).

\section{CONCEPTUAL FRAMEWORK}

Based on the theoretical explanation that has been described, this study aims to examine the indirect effects of learning goal orientation (adaptivity) on self-perceived employability (adaptation result) through career adaptability. A study conducted by Tolentino et al. (2014) found that learning goal orientation relates positively with four dimensions of career adaptability, that is concern, control, curiosity, and confidence. Other study found that career adaptability relates to self-perceived employability (Rudolph et al., 2017; Udayar et al., 2018). Therefore, the hypothesis of this study is career adaptability will mediate the relationship between learning goal orientation and self-perceived employability. 


\section{METHODS OF RESEARCH}

Participants in this study consist of 69 college students from several universities in Indonesia, with as much as $50,7 \%$ of bachelor and $49,3 \%$ of master students from various disciplines. The age or participants varies between $21-30$ years and dominated by women, namely as many as 58 people or $84,1 \%$ of the total participants.

Learning goal orientation was measured by Learning Goal Orientation Scale, developed by Button et al. (1996) that consist of 8 items measuring learning goal orientation indicators. Career adaptability was measured by The Career Adapt-Abilities Scales Form 2.0 (CAAS), developed by Savickas and Profeli (2012). CAAS scale consists of 24 items measuring four dimensions of career adaptability with each dimension represented by 6 items. Self-perceived employability was measured by Student Self-Perceived Employability, developed by Rothwell et al. (2009) that consists of 16 items measuring hope and selfperceptions about employability on college students.

\section{RESULTS OF STUDY}

In this study, data were analyzed using simple linear regression test and multiple linear regression test techniques. Before conducting a regression analysis, researchers tested the correlation between variables.

Table 1 - Correlation Statistics Results

\begin{tabular}{|c|l|c|c|c|}
\hline $\mathrm{n} / \mathrm{n}$ & \multicolumn{1}{|c|}{ Variable } & 1 & 2 & 3 \\
\hline 1 & Learning goal orientation & 1 & 0.508 & 0.333 \\
\hline 2 & Career Adaptability & 0.508 & 1 & 0.526 \\
\hline 3 & Self-perceived employability & 0.333 & 0.526 & 1 \\
\hline
\end{tabular}

Based on the correlation test results, the three correlation results in this study are classified as significant with significance value of less than 0,05 at a significance level of $5 \%$. The strength of the correlation between learning goal orientation variable with career adaptability is high, which is equal to 0,508 . The strength of the correlation between learning goal orientation and self-perceived employability is classified as moderate, which is equal to 0,333 . While the strength of the correlation between career adaptability and self-perceived employability is high, amounting to 0,526 . The correlation value of all variables shows a positive correlation so that when learning goal orientation increases, career adaptability and self-perceived employability will also increase. Likewise, if career adaptability increases, learning goal orientation and self-perceived employability will also increase.

Table 2 - Regression Analysis Results

\begin{tabular}{|c|c|c|c|c|c|c|}
\hline $\mathrm{n} / \mathrm{n}$ & Regression Model & R Square & B Value & Beta & Sig. & Information \\
\hline 1 & $\mathrm{X} \rightarrow \mathrm{Y}$ & 0.111 & 0.444 & 0.333 & 0.000 & Significant \\
\hline 2 & $\mathrm{X} \rightarrow \mathrm{Z}$ & 0.258 & 1.122 & 0.508 & 0.000 & Significant \\
\hline \multirow{2}{*}{3} & $\mathrm{X} \& \mathrm{Z} \rightarrow \mathrm{Y}$ & \multirow{2}{*}{0.283} & $0.118(\mathrm{X})$ & 0.089 & 0.466 & Not significant \\
& & & $0.290(\mathrm{Z})$ & 0.481 & 0.000 & Significant \\
\hline
\end{tabular}

After conducting a correlation test, researchers conducted a mediation test. Baron and Kenny (1986) explain that the role of mediator on the influence of independent and dependent variables will be fulfilled if they are in three conditions, that is (1) the value of predictor estimation from regression of dependent variable $(\mathrm{Y})$ with independent variable $(\mathrm{X})$ is expected that the result is significant; (2) the value of the predictor estimation from the regression of mediator variable $(Z)$ with independent variable $(X)$ is expected to have a significant result; (3) the results of the regression of dependent variable $(Y)$ with independent variable $(X)$ with mediator variable $(Z)$ as predictors are significant, while the value of $X$ on $Y$ is not significant. Perfect mediation will be obtained if the magnitude of the influence of the 
independent variable $(\mathrm{X})$ on the dependent variable $(\mathrm{Y})$ in the third equation is smaller than the effect of the two in the first equation.

Based on table 2, it can be seen that the results of the regression analysis meet the first and second conditions, where the value obtained is significant with an estimated predictor value of 0.444 and 0.122 . In the third condition, the mediator variable is proven to affect the dependent variable with the control of the independent variable. This can be seen from the results of multiple regression of $X$ on $Y$ which is not significant, with a significance level of 0.466 with an estimated predictor value of 0.118 . The multiple regression results of $Z$ on $Y$ show a significance level of 0.000 with estimated predictor value of 0.290 . The estimated predictor value of $X$ on $Y$ in the third equation is proven to be smaller than the first equation, which is equal to 0.089 . Thus, the hypothesis in this study which stated that career adaptability will mediate the relationship between learning goal orientation and self-perceived employability is accepted and is a perfect mediation.

\section{DISCUSSION OF RESULTS}

This study aims to determine the effect of learning goal orientation on self-perceived employability with career adaptability as a mediator. The results of the regression analysis using the Baron and Kenny mediation tests show that career adaptability acts as a mediator in the influence of learning goal orientation on self-perceived employability.

The results of the first equation in the mediation test analysis show that learning goal orientation affects self-perceived employability. However, this influence tends to be low so it is proven that the relationship between learning goal orientation and self-perceived employability requires other variables to strengthen the relationship between the two. This shows that even though students have an effort to continue to develop competence and persevere in facing challenges, they are not necessarily able to get the desired job.

The results of the second equation show that learning goal orientation influences career adaptability. This is aligned with the study conducted by Tolentino et al (2014), where individuals who have learning goal orientation tend to develop career adaptability resources to increase their competencies and survive in facing obstacles. Individuals who continue to strive to develop competencies will be more motivated to think and prepare for their future (concern), improve discipline and responsibility in making career decisions (control), explore and look for opportunities (curiosity), and be more confident in solving problems (confidence).

The third equation shows that the influence of learning goal orientation on selfperceived employability will be stronger if mediated by career adaptability. The results of this study prove that when individuals try to continue to develop their competencies, they will also be better prepared to face all the demands of the role. When individuals are better prepared to face all demands, the individual also feels better able to get the desired job.

\section{CONCLUSION}

Based on the results of this study, it can be concluded that career adaptability plays a mediating role in the effect of learning goal orientation on self-perceived employability. Individuals who are always trying to develop their competencies will be better able to carry out adaptive actions so that they will also perceive that they can get the desired job. That way, the hypothesis in this study is accepted. The results of this study also show that there is a positive relationship between learning goal orientation with career adaptability and selfperceived employability.

With the limitations of generalizations in this study, further research is expected to replicate studies in samples that are more diverse in terms of geographical area, the field of study or profession, and career stages. Further research can also consider other variables that act as mediators in the influence between learning goal orientation and self-perceived employability. 


\section{REFERENCES}

1. Button, Scott B., Mathieu, J. E., \& Zajac, D. M. (1996). Goal orientation in organizational research: A conceptual and empirical foundation. Organizational Behavior and Human Decision Processes, Vol. 67, No. 1, 26-48.

2. Creed, Peter A., Fallon, Tracy.,\& Hood, Michelle. (2009). The relationship between career adaptability, person and situation variables, and career concerns in young adults. Journal of Vocational Behavior, 74, 219-229.

3. De Cuyper, N., \& De Witte, H. (2011). The management paradox: Self-rated employability and organizational commitment and performance. Personnel Review, 40(2), 152-172.

4. Dweck, C. S. (1986). Motivational processes affecting learning. American Psychologist. 41, 1040-1048.

5. Fugate, M., Kinicki, A. J., \& Ashforth, B. E. (2004). Employability: A psycho-social construct, its dimensions, and applications. Journal of Vocational behavior, 65(1), 14-38.

6. Koen, Jessie., Klehe, Ute-Christine., \& Van Vianen, Annelies E.M. (2012). Training career adaptability to facilitate a successful school-to-work transition.Journal of Vocational Behavior, 81, 395-408.

7. Manyika, J., Lund, S., Chui, M., Bughin, J., Woetzel, J., Batra, P., ... \& Sanghvi, S. (2017). Jobs lost, jobs gained: Workforce transitions in a time of automation. McKinsey Global Institute.

8. Rothwell, A., \& Arnold, J. (2007). Self-perceived employability: development and validation of a scale. Personnel review, 36(1), 23-41.

9. Rothwell, A., Jewell, S., \& Hardie, M. (2009). Self-perceived employability: Investigating the responses of post-graduate students. Journal of vocational behavior, 75(2), 152-161.

10. Rudolph, C. W., Lavigne, K. N., \& Zacher, H. (2017). Career adaptability: A meta-analysis of relationships with measures of adaptivity, adapting responses, and adaptation results. Journal of Vocational Behavior, 98, 17-34.

11. Savickas, Mark L., \& Profeli, Erik J. (2012). Career adapt-abilities scale: Construction, reliability, and measurement equivalence across 13 countries. Journal of Vocational Behavior, 80, 661-673.

12. Tolentino, L. R., Garcia, P. R. J. M., Lu, V. N., Restubog, S. L. D., Bordia, P., \& Plewa, C. (2014). Career adaptation: The relation of adaptability to goal orientation, proactive personality, and career optimism. Journal of Vocational Behavior, 84(1), 39-48.

13. Udayar, S., Fiori, M., Thalmayer, A. G., \& Rossier, J. (2018). Investigating the link between trait emotional intelligence, career indecision, and self-perceived employability: The role of career adaptability. Personality and Individual Differences, 135, 7-12.

14. Van Dam, K. (2004). Antecedents and consequences of employability orientation. European Journal of work and organizational Psychology, 13(1), 29-51.

15. Veiga, Serge P. M., \& Turban, Daniel B. (2014). Are affect and perceived stress detrimental or beneficial to job seekers? The role of learning goal orientation in job search self-regulation. Organizational Behavior and Human Decision Processes, 125, 193-203.

16. Yi, Mun, Y., \& Hwang, Yujong (2003). Predicting the use of web-based information systems: self-efficacy, enjoyment, learning goal orientation, and the technology acceptance model. Int. J. Human-Computer Studies, 59, 431-449. 